\title{
Relevant Factors for Sarcopenia in Hyperthyroidism Patients
}

\author{
Zhenchao Liu', Feifei Xia' ${ }^{1}$, Xinbo Zhao², Donghao Zhou ${ }^{2}$ \\ ${ }^{1}$ Institute of Integrative Medicine, Qingdao University Medical College, Qingdao, China \\ ${ }^{2}$ Qingdao University Eleventh Hospital (Linyi People's Hospital), Qingdao, China \\ Email: hanfangyixue@126.com
}

How to cite this paper: Liu, Z.C., Xia, F.F., Zhao, X.B. and Zhou, D.H. (2018) Relevant Factors for Sarcopenia in Hyperthyroidism Patients. Open Access Library Journal, 5: e4620.

https://doi.org/10.4236/oalib.1104620

Received: April 25, 2018

Accepted: May 15, 2018

Published: May 18, 2018

Copyright $\odot 2018$ by authors and Open Access Library Inc.

This work is licensed under the Creative Commons Attribution International License (CC BY 4.0).

http://creativecommons.org/licenses/by/4.0/

\begin{abstract}
In recent years, sarcopenia began to receive attention. Not only the elderly, hyperthyroidism patients also suffer from sarcopenia. The purpose of this study is to explore the relevant factors for sarcopenia in hyperthyroidism patients. [Methods]: Dual energy X-ray was used to detect the muscle mass in 101 hyperthyroidism patients (23 males and 78 females, mean age $45.77 \pm$ 15.02 years), and calculate SMI. Pearson correlation analysis was performed to examine the relationship between SMI and Age, BMI, Fat amount, Grip, SBP, DBP, FT3, FT4, TSH, Ca, P, TC, TG, LDL-C, HDL-C, FPG, LA, IL-6, TNF-a respectively. Spearman correlation analysis was performed to examine the relationship between gender respectively. The influencing factors of relative SMI status were selected by stepwise regression analysis. [Results]: Based on Pearson and Spearman analysis, Gender $(\mathrm{r}=-0.567, p<0.001)$, BMI $(\mathrm{r}=0.245, p$ $=0.014)$, grip $(\mathrm{r}=0.670, p<0.001)$, TC $(\mathrm{r}=0.221, p=0.026)$, lactic acid $(\mathrm{r}=$ $-0.196, p=0.050)$ is significantly correlated with sarcopenia in hyperthyroidism patients. Stepwise regression analysis showed that there existed the close correlations between gender, BMI, grip and SMI, $\mathrm{Y}=4.805-0.985$ gender + $0.044 \mathrm{BMI}+0.045$ grip. [Conclusion]: As a risk of sarcopenia in hyperthyroidism patients, there was a correlation with gender, grip strength and BMI. Not only the elderly, young patients with hyperthyroidism should also pay attention to sarcopenia.
\end{abstract}

\section{Subject Areas}

Geriatrics, Metabolic Sciences, Orthopedics

\section{Keywords}

Sarcopenia, Hyperthyroidism, Risk Factors 


\section{1.はじめに}

近年からサルコペニアが注目されている、その病症は筋肉量の減少、筋力 及び体力の低下、そして、転びや骨折のリスクは健常者よりはるかに高く なるので、患者の暮らしに支障が出ている。统一された诊断基准がなくて、 また人种、生活习惯、身体活动の违いの原因で、サルコペニアの調査結果 には明確的な差異がある。先行研究の统计によると、現在の世界における サルコペニア患者数は约 50 万人とされて、2050 年までに総人口が 200 万人 を突破したと予测されている[1]。先行研究によると、サルコペニアの病因 は复雑で、运动、栄养、免疫、ホルモン、神経などが年齢とともにサルコ ペニアのリスクは大くなる。年齢が増えて、体機能が低くて、体内で慢性 炎症になるとともに[2]、IL-6 や TNF- $\alpha$ などの炎症性サイトカインの異常は 筋肉量が減少される[3] [4]。そして、性ホルモンと運動神経細胞の下降[5] [6]、mTORC1 の活性低下のため蛋白質を合成機能が低くなって [7]、以上の ことでサルコペニアが起こられる。年齢、栄養のアンバランス、運動不足 のほかに、甲状腺机能六进症、糖尿病、腫瘍などの慢性消耗病はサルコペ ニアが起こられるが、年齢の増えと病気に関する筋肉量の変化は現在分別 することができない。先行研究によると、甲状腺机能六进症は二次性サル コペニアの原疾患て、多くの甲状腺机能六进症患者の体が瘦せて行いて、 その体重减少の部分は筋肉量であり、脂肪ではない[8]。けれども、甲状腺 机能六进症者のサルコペニアについてに关系する因子の报告される研究が まだ见つからない。

そこで、本研究は甲状腺机能六进症者対象として、甲状腺机能立进症者 のサルコペニアに关连する要因を検讨した。

\section{2. 対象と研究方法}

\section{1. 対象}

2016 年 11 月から 2017 年 11 月末までに甲状腺机能六进症で青岛大学附属第 十一病院(临沂市人民病院)に入院した 101 例のうち、(男性 23 名, 女性 78 名、平均年齢 $45.77 \pm 15.02$ 歳)を対象とした。本研究は、青岛大学附属第十 一病院(临沂市人民病院)の伦理审査委员会により承认を得た(承认番号:

KY2017015)。また、全ての対象に対して书面による说明を行った。

\subsection{1. サルコペニアの判断基準}

サルコペニアの判断基准は Asian Working Group for Sarcopenia (AWGS)の 基准に従った[9]。歩行速度 $0.8 \mathrm{~m} / \mathrm{s}$ 以下、または握力: 男性 $26 \mathrm{~kg}$ 、女性 18 $\mathrm{kg}$ 未満と SMI : 男性 $7.00 \mathrm{~kg} / \mathrm{m}^{2}$ 、女性 $5.40 \mathrm{~kg} / \mathrm{m}^{2}$ 未満を満たした者をサルコ ペニアと判定した。

\subsection{2. 付け加えの基准}

（1）18 歳以上の甲状腺机能立进症(2)サルコペニアの诊断の基准に合う甲状 腺机能え进症(サルコペニア群) (3)SMI 指标が正常な甲状腺机能立进症(非 サルコペニア群)。 


\subsection{3. 対象外になる基准}

(1)ほかの持病を合并している患者(2)サルコペニアに副作用を与えるホル モン关连の薬物を长期的に饮む患者(3)身体障害があるあるいは病状が深 刻な女性患者。

\section{2. 測定項目}

\section{1) 筋肉量と握力}

筋肉量は DPX 法测定 L (GE, USA), skeletal muscle mass index (SMI)を求め た, $\mathrm{SMI}=$ 四肢除脂肪软组织量 $(\mathrm{AMM}) /$ 身长 $\left(\mathrm{m}^{2}\right)$ 。同时に, 歩行速度と握力 (CAMRY EH101, China)を 3 回测定し, 最も高い值を测定值として采用した。

\section{2) 血液生化学}

患者入院时游离トリヨードサイロニン(FT3)、游离サイロキシン(FT4)、 甲状腺刺激ホルモン( TSH ) 検査值を取集した。血液と生化検査值として、 早朝に空腹様态を静脉から采取した血液から、総コレステロール(TC)、卜 リグリセリド(TG)、LDL コレステロール(LDL-C)、HDL コレステロール (HDL-C)、血液中の $\mathrm{C}$ a と P 浓度を病院の生化室によって测定した。乳酸 (LA)を Accutrend PLUS(USA)によって测定した。IL-6、TNF-a を ELISA 法に よって测定した。

\section{3）血压}

安静时计测としては、収缩期血圧おょび拡张期血圧を全身血圧计 (YUWELL, China)によって测定した。

\section{3. 统计解析}

统计解析ソフトはSPSS 21.0 を使用し、筋量(Muscle volume)、年齢(Age)、 身长(Height)、体重(Body weight)、BMI、SMI、脂肪量(Fat amount)、握力(Grip)、 収缩期圧(SBP)、拡张期圧(DBP)、FT3、FT4、TSH、Ca、P、TC、TG、LDL-C、 HDL-C、FPG、LA、IL-6、TNF-a なとは $\mathrm{t}$ 検定で群间差を比较した。性别 (Gender)はカイ二乗検定を比较した。SMI と年齢(Age)、BMI、TG、脂肪量 (Fat amount)、握力(Grip)、収缩期圧(SBP)、拡张期圧(DBP)、FT3、FT4、TSH、 Ca、P、TC、TG、LDL-C、HDL-C、FPG、LA、IL-6、TNF-a との关系をピ アソンの积率相关系数を用いて、SMI と性别との关系をスピアマンの顺位 相关系数を用いて解析した、性别のカテゴリ一化は男性を 0 女性を 1 とし た。また、影响を及ぼす因子の关连性をステップワイズ回帰分析を用いて 検讨した。有意水平はすべて $p<0.05$ とした。

\section{3. 结果}

サルコペニアの有病率は 41.58\% (42 例、男 13 例、女 29 例)であった。表 1 から见ると、有症者の筋肉量 $(t=-2.764, p=0.007) 、 A M M(t=-3.664 、 p<$ $0.001)$ と体重 $(t=-3.339, p=0.001)$ が着しく低下した。血液検査值から见る と、サルコペニア非有症者に比べて、FT3 $(t=2.039, p=0.044) 、 \operatorname{FT} 4(t=2.930$, $p=0.004) 、 \mathrm{Ca}(t=2.856, p=0.005)$ と IL-6 $(t=2.019, p=0.046)$ 差异が認められ た(Table 1)。

ピアソンの相关系数検定て, SMI の有意な关连性が认められたのは性别、 
Table 1. Comparison of the results between the two groups $(\bar{x} \pm s)$.

\begin{tabular}{|c|c|c|c|c|}
\hline & Sarcopenia & Non-sarcopenia & $t$ or $\chi^{2}$ & $p$ \\
\hline Age (years) & $46.48 \pm 15.70$ & $44.76 \pm 13.68$ & 0.583 & 0.561 \\
\hline Gender (male/female) & $13 / 29$ & $10 / 49$ & 2.736 & 0.098 \\
\hline Height $(\mathrm{cm})$ & $161.79 \pm 7.58$ & $162.09 \pm 7.88$ & -0.192 & 0.848 \\
\hline Body weight $(\mathrm{kg})$ & $55.89 \pm 10.39$ & $62.56 \pm 9.52$ & -3.339 & 0.001 \\
\hline BMI $\left(\mathrm{Kg} / \mathrm{m}^{2}\right)$ & $20.86 \pm 4.59$ & $23.79 \pm 3.03$ & -3.868 & $<0.001$ \\
\hline SMI $\left(\mathrm{Kg} / \mathrm{m}^{2}\right)$ & $5.44 \pm 0.79$ & $6.45 \pm 0.95$ & -5.643 & $<0.001$ \\
\hline $\mathrm{AMM}(\mathrm{kg})$ & $14.44 \pm 3.18$ & $17.01 \pm 3.68$ & -3.664 & $<0.001$ \\
\hline Muscle volume (kg) & $34.72 \pm 6.54$ & $38.51 \pm 6.96$ & -2.764 & 0.007 \\
\hline Fat amount $(\mathrm{kg})$ & $16.15 \pm 6.90$ & $18.78 \pm 8.22$ & -1.690 & 0.094 \\
\hline Grip (kg) & $16.31 \pm 8.14$ & $26.25 \pm 10.23$ & -5.195 & $<0.001$ \\
\hline SBP (mmHg) & $124.67 \pm 11.92$ & $125.46 \pm 13.43$ & -0.305 & 0.761 \\
\hline DBP $(\mathrm{mmHg})$ & $78.67 \pm 9.61$ & $79.83 \pm 10.30$ & -0.575 & 0.566 \\
\hline $\mathrm{FT}^{2}(\mathrm{pmol} / \mathrm{l})$ & $23.43 \pm 9.27$ & $19.09 \pm 11.35$ & 2.039 & 0.044 \\
\hline $\mathrm{FT} 4^{3}(\mathrm{pmol} / \mathrm{l})$ & $64.19 \pm 32.24$ & $45.96 \pm 29.78$ & 2.930 & 0.004 \\
\hline $\mathrm{TSH}^{4}(\mathrm{mIU} / \mathrm{ml})$ & $0.008 \pm 0.007$ & $0.025 \pm 0.077$ & -1.753 & 0.085 \\
\hline $\mathrm{Ca}(\mathrm{mmol} / \mathrm{L})$ & $2.40 \pm 0.31$ & $2.27 \pm 0.15$ & 2.856 & 0.005 \\
\hline $\mathrm{P}(\mathrm{mmol} / \mathrm{L})$ & $1.52 \pm 0.31$ & $1.46 \pm 0.29$ & 0.986 & 0.327 \\
\hline $\mathrm{TC}^{5}(\mathrm{mmol} / \mathrm{L})$ & $3.60 \pm 1.20$ & $3.79 \pm 1.26$ & -0.772 & 0.442 \\
\hline $\mathrm{TG}^{6}(\mathrm{mmol} / \mathrm{L})$ & $1.12 \pm 0.54$ & $1.16 \pm 0.53$ & -0.382 & 0.703 \\
\hline $\mathrm{LDL}-\mathrm{C}^{7}(\mathrm{mmol} / \mathrm{L})$ & $1.92 \pm 0.57$ & $1.90 \pm 0.84$ & 0.109 & 0.913 \\
\hline $\mathrm{HDL}^{-\mathrm{C}^{8}}(\mathrm{mmol} / \mathrm{L})$ & $1.20 \pm 0.27$ & $1.20 \pm 0.28$ & 0.063 & 0.950 \\
\hline $\mathrm{FPG}^{9}(\mathrm{mmol} / \mathrm{L})$ & $5.52 \pm 1.38$ & $5.12 \pm 0.90$ & 1.770 & 0.080 \\
\hline $\mathrm{LA}^{10}(\mathrm{mmol} / \mathrm{L})$ & $2.20 \pm 0.87$ & $1.88 \pm 0.83$ & 1.896 & 0.061 \\
\hline $\mathrm{IL}^{-} 6^{11}(\mathrm{pg} / \mathrm{ml})$ & $24.61 \pm 7.64$ & $21.32 \pm 8.34$ & 2.019 & 0.046 \\
\hline TNF-a $^{12}(\mathrm{pg} / \mathrm{ml})$ & $39.40 \pm 21.47$ & $32.40 \pm 15.63$ & 1.801 & 0.076 \\
\hline
\end{tabular}

${ }^{2}$ free Triiodothyronine; ${ }^{3}$ free thyroxine; ${ }^{4}$ thyroid stimulating hormone; ${ }^{5}$ total cholesterol; ${ }^{6}$ triglyceride; ${ }^{7}$ low density lipoprotein; ${ }^{8}$ high density lipoprotein; ${ }^{9}$ fasting plasma glucose; ${ }^{10}$ lactic acid; ${ }^{11}$ interleukin $6 ;{ }^{12}$ tumor necrosis factor- $\alpha$.

BMI、握力、TC、LA であった。S M I と BMI は、ピアソン相関係数で正 の相関 $(\mathrm{r}=0.245 、 p=0.014)$ が認められた、S M I と握力も，ピアソン相関 係数で正の相関 $(\mathrm{r}=0.670 、 p<0.001)$ が認められた、S M I と T C も、ピア ソン相関係数で正の相関 $(\mathrm{r}=0.221 、 p=0.026)$ が認められた。S M I と L A は, ピアソン相関係数で负の相関 $(\mathrm{r}=-0.196, p=0.050)$ が認められた。SMI と性别 $(\mathrm{r}=-0.567, p<0.001)$ はスピアマン相关系数で负の相关が认められ た。年齢 $(\mathrm{r}=0.104, p=0.303)$ なと、相関が認められなかった。SMI と各項 目との関係を表 2 に示す(Table 2)。

FT3、FT4、TSH と SMI は相关が认められなかった、しかし、FT3 と握力 は、ピアソン相关系数で负の相关 $(\mathrm{r}=-0.201, p=0.044)$ が认められた。

SMI と影响を及ぼす因子の検讨、SMI を従属变数として、年齢、性别、 BMI、脂肪、握力、収缩期圧、拡张期圧、FT3、FT4、TSH、Ca、P、TC、 TG、LDL-C、HDL-C、FPG、LA、IL-6、TNF-a を独立变数としたステップ ワイズ回帰分析の结果は、影响を及ぼす因子として性别、BMI と握力を抽 出した。SMI の有意な独立变数として性别 $(\beta=-0.985, p<0.001), \mathrm{BMI}(\beta=$ 
Table 2. Correlation analysis between smi and various factors.

\begin{tabular}{|c|c|c|}
\hline & Correlation coefficient $(\mathrm{r})$ & $p$ \\
\hline Age $^{a}$ & 0.104 & 0.303 \\
\hline Gender $^{\mathrm{b}}$ & -0.567 & $<0.001$ \\
\hline $\mathrm{BMI}^{\mathrm{a}}$ & 0.245 & 0.014 \\
\hline Fat amount ${ }^{\mathrm{a}}$ & -0.070 & 0.487 \\
\hline Grip $^{\mathrm{a}}$ & 0.670 & $<0.001$ \\
\hline $\mathrm{SBP}^{\mathrm{a}}$ & 0.124 & 0.218 \\
\hline $\mathrm{DBP}^{\mathrm{a}}$ & -0.017 & 0.866 \\
\hline $\mathrm{FT}^{\mathrm{a}}$ & -0.155 & 0.122 \\
\hline $\mathrm{FT} 4^{\mathrm{a}}$ & -0.176 & 0.078 \\
\hline $\mathrm{TSH}^{\mathrm{a}}$ & 0.031 & 0.757 \\
\hline $\mathrm{Ca}^{\mathrm{a}}$ & -0.016 & 0.874 \\
\hline $\mathrm{P}^{\mathrm{a}}$ & -0.098 & 0.331 \\
\hline $\mathrm{TC}^{\mathrm{a}}$ & 0.221 & 0.026 \\
\hline $\mathrm{TG}^{\mathrm{a}}$ & -0.016 & 0.877 \\
\hline LDL-C $^{\mathrm{a}}$ & 0.046 & 0.651 \\
\hline HDL-C ${ }^{a}$ & 0.055 & 0.588 \\
\hline FPG $^{\mathrm{a}}$ & -0.069 & 0.491 \\
\hline $\mathrm{LA}^{\mathrm{a}}$ & -0.196 & 0.050 \\
\hline IL-6 ${ }^{\mathrm{a}}$ & 0.100 & 0.321 \\
\hline TNF-a ${ }^{a}$ & -0.016 & 0.873 \\
\hline
\end{tabular}

${ }^{\mathrm{a} P e a r s o n}$ correlation coefficient, ${ }^{\mathrm{b}}$ Spearman correlation coefficient.

$0.044, p=0.013)$ と握力 $(\beta=0.045, p<0.001)$ であった $(\mathrm{R} 2=0.591$ 、调整済み $\mathrm{R} 2=$ $0.579)$ 。方程式は: $\mathrm{Y}=4.805-0.985$ 性别 $+0.044 \mathrm{BMI}+0.045$ 握力 $(p<0.01)$ (Table 3)。

\section{4. 考察}

加齢はサルコペニアの発症に一番大きなリスクである。先行研究によると、 60 歳から 70 歳までの人がサルコペニアになる割合は $5 \%$ から $13 \%$ だが、8 歳以上の人の場合は $11 \%$ から $50 \%$ になると報告されている[10]。AWGS は 65 歳以上の人をサルコペニアのスクリーニングの主な対象にすることに意 見を一致した[9]。しかしながら、本研究において、加齡が甲状腺機能六進 症の患者のサルコペニアとの関係性はあまりなく、甲状腺機能六進症に伴 うサルコペニアは 65 歳未満の患者にも存在する。甲状腺機能六進症の患者 の FT3、FT4 の増加に伴い、血清のフリーの IL6、TNF-a のレベルが高くな るので[11]、この二つの炎症細胞因子ともはサルコペニアと関係している [3] [4]。また、甲状腺機能六進症は筋肉のアミノ酸を放出し、筋肉のタンパ ク质の分解を促进するので、筋肉量が減少する[12]。けれども、そういうの は甲状腺機能六進症の患者がサルコペニアになる潜在的なメカニズムでは なく、甲状腺機能六進症のホルモンの異常がサルコペニアに大いに関係し ている。そして、甲状腺機能六進症はいくつでもかかる可能性がある病気 
Table 3. Regression analysis between smi and each project.

\begin{tabular}{cccccc}
\hline variable & $\begin{array}{c}\text { regression } \\
\text { coefficient } \\
(\beta)\end{array}$ & $\begin{array}{c}\text { standard } \\
\text { error }(\text { SEB })\end{array}$ & $\begin{array}{c}\text { standardized } \\
\text { regression } \\
\text { coefficient }(\beta)\end{array}$ & $t$ & $P$ \\
\hline constant term & 4.805 & 0.396 & & 12.130 & $<0.001$ \\
Gender & -0.985 & 0.174 & -0.409 & -5.675 & $<0.001$ \\
BMI & 0.044 & 0.017 & 0.173 & 2.519 & 0.013 \\
Grip & 0.045 & 0.007 & 0.472 & 6.384 & $<0.001$ \\
\hline
\end{tabular}

なので、甲状腺機能六進症の患者のサルコペニアは加齢と直接な関係を持 っていないと考えられる。それにしても、加齢が甲状腺機能立進症の患者 のサルコペニアへの影響を考えに入れないといけない。Jilip など[8]は甲状 腺機能六進症のサルコペニアの猫を対象にした実験によって、甲状腺機能 六進症が治っても筋肉量が回復しない猫は半数を占めているので、その結 果は甲状腺機能元進症だけではなく、加齢と関係していると示されている。

本研究では、性別がサルコペニアになる独立の相関要因であると示され ている。Di Monaco など[13]の研究によると、男性の場合はサルコペニアに なる割合が女性より高いと判明された。その原因は性ホルモンにかかわっ ていると考えられる。先行研究によると、テストステロンは筋肉の蛋白質 の合成を促進させるが[14]、加齢とともに、男性のテストステロンは毎年 $1 \%$ \%すで減少していくので[15]、男性のサルコペニアの発症に大いにつな がっていると示される。女性ホルモンに関する研究では、女性ホルモンは 核内受容体と G-蛋白質やエストロゲン受容体の結合部によって筋肉力を 上げると報告される[16]。Taaffeなど[17]の研究では、女性ホルモンの代替 治療によって、大腿四頭筋の横断面積がより高いが、膝のストレッチの強 度と関係がないと報告されている。したがって、テストステロンょり、女 性ホルモンは筋肉の強度に関係しているが、サルコペニアになる重要な原 因ではないと推測される。先行研究では、甲状腺機能立進症患者のテス卜 ステロンは健常者と差があまりないが、甲状腺機能六進症患者の SHBG の 上昇がフリーのテストステロンを減少させると示されている[18]。Lorie な ど[19]の研究では、甲状腺機能立進症患者の血清の SHBG の上昇がフリー のテストステロンを減少させ、テストステロンが体組織への有効性が下が ると報告されているが、Gower など[20]の研究では、筋肉量と足の筋肉量 はテストステロンの濃度と関係がなく、フリーのテストステロンとの関係 性が明らかであると示される。したがって、フリーのテストステロンの变 化は甲状腺機能六進症のサルコペニアにあらわれる性別の差異につながっ ていると推測される。また、女性の場合は、脂肪が筋肉の保護に役立って いるのだ。要するに、そのメカニズムをはっきりさせるには、研究をより 深く進めなければならない。

先行研究では、サルコペニア患者は IL-6 と TNF- $\alpha$ の上昇が伴い、IL-6 と TNF- $\alpha$ はサルコペニアと関係していると報告されている[21]。IL-6は筋 肉の蛋白質の合成を妨げ、蛋白質の分解に直接関与するので[21]、筋肉量の 減少につながっているが[22]、TNF- $\alpha$ は LPL の活性化を抑え、蛋白質の形 成を妨げ、また、筋肉の蛋白質の分解を加速させ、筋肉の分解を促進させ 
る[4]。本研究において、甲状腺機能六進症のサルコペニア患者の IL-6 は甲 状腺機能六進症の非サルコペニア患者よりはるかに高いが $(p<0.05) 、 I L-6$ と TNF- $\alpha$ は甲状腺機能え進症のサルコペニアと関係しているのが判明され ていない。それは甲状腺機能六進症患者自身には IL-6 と TNF- $\alpha$ の上昇が伴 っていると考えられるが、それらの炎症細胞因子が甲状腺機能六進症のサ ルコペニアにどんな役割を果たしているかを判明するために、より深い研 究が必要だと思う。

BMI は甲状腺機能六進症のサルコペニアの独立した相関要因であると考 えられる。Goodman など[23]の研究では、研究対象の中で筋肉量が減少し た人は筋肉量が健常者より BMI が低いという結果が出されている。ロジス ティック回帰の分析によると、SMI と年齢、BMI の相関性が明らかで、そ の予測モデルが検証サンプルでょい効果を出していると示され、本研究の 結果と一致している。低い BMI と甲状腺機能六進症の患者がサルコペニア になる可能性があると考えられる。それとともに、握力ももう一つの独立 した相関要因として甲状腺機能六進症のサルコペニアの評価項目に取り入 れょうと考えられる。したがって、甲状腺機能六進症の患者の BMI と握力 が低下すると、サルコペニアのスクリーニングを行う必要があると考えら れる。

この研究は、加齢、IL-6 と TNF- $\alpha$ および他の因子が甲状腺機能六進症の 独立因子ではないことを見出したが、これはサンプルサイズおよび他の因 子の減少に関係し、年齢おょび甲状腺機能六進が増加すると IL-6したがっ て、甲状腺機能六進症患者の異なる段階をさらに研究する必要があります。

\section{5. 结论}

本研究では、性別、BMI、握力と共に独立して SMIに関連する要因であっ た。高齢甲状腺機能六進症者だけではなく、いろいろなメカニズムの働き で、甲状腺機能六進症の若い患者もサルコペニアの合併症になる可能性が あるので、特に BMI と握力が低下する患者はサルコペニアに気を付けるべ きだと考えられる。そして、甲状腺機能え進症のサルコペニアは性別の差 異が存在すると示される。しかし, 本研究において, IL-6 や TNF- $\alpha$ と握力 は相関が認められなかった。

\section{References}

[1] Santilli, V., Bernetti, A., et al. (2014) Clinical Definition of Sarcopenia. Clinical Cases in Mineral and Bone Metabolism, 11, 177-180. https://doi.org/10.11138/ccmbm/2014.11.3.177

[2] Handschin, C. and Spiegelman, B.M. (2008) The Role of Exercise and PGC1alpha in Inflammation and Chronic Disease. Nature, 454, 463-469. https://doi.org/10.1038/nature07206

[3] Wang, J.-Y. and Wang, X.-H. (2012) Effect of p38,NF-кB and IL-6 on Pathogenesis of Sarcopenia and It's Exercise-Induced Improvement. Journal of Shandong Institute of Physical Education and Sports, 28, 51-56.

[4] Onamb, G.L., Xe, P., et al. (2010) Influence of Exercise Intensity in Older Persons with Unchanged Habitual Nutritional Intake: Skeletal Muscle and Endocrine Adap- 
tations. $A G E, 32,139-153$. https://doi.org/10.1007/s11357-010-9141-0

[5] Sipil, S., Narici, M., et al. (2013) Sex Hormones and Skeletal Muscle Weakness. Biogerontology, 14, 231-245. https://doi.org/10.1007/s10522-013-9425-8

[6] 重本和宏, 森秀一他 (2013) 筋肉と神経のシナプスの老化(サルコペニア)の基 础研究. 日本老年医学会雑志, 50, 349-351.

[7] 若林秀隆(2016) リハビリテ-ション栄养とサルコペニア. 外科と代谢.栄养, 50, 43-49.

[8] Peterson, M.E., Castellano, C.A., et al. (2016) Evaluation of Body Weight, Body Condition, and Muscle Condition in Cats with Hyperthyroidism. Journal of Veterinary Internal Medicine, 30, 1780-1789. https://doi.org/10.1111/jvim.14591

[9] Chen, L.K., Liu, L.K., et al. (2014) Sarcopenia in Asia: Consensus Report of the Asian Working Group for Sarcopenia. Journal of the American Medical Directors Association, 15, 95-101. https://doi.org/10.1016/j.jamda.2013.11.025

[10] Morley, J.E. (2008) Sarcopenia: Diagnosis and Treatment. The Journal of Nutrition, Health \& Aging, 12, 452. https://doi.org/10.1007/BF02982705

[11] Kiziltunç, A., Basoğlu, M., et al. (1999) Serum IL-6 and TNF-\Alpha in Patients with Thyroid Disorders. Turkish Journal of Medical Sciences, 25-30.

[12] Riis, A.L., Jørgensen, J.O., et al. (2005) Whole Body and Forearm Substrate Metabolism Inhyperthyroidism: Evidence of Increased Basal Muscle Protein Breakdown. American Journal of Physiology Endocrinology Metabolism, 288, 1067-1073. https://doi.org/10.1152/ajpendo.00253.2004

[13] Monaco, D., Castiglioni, C., et al. (2012) Sarcopenia Is More Prevalent in Men than in Women after Hip Fracture: A Cross-Sectional Study of 591 Inpatients. Archives of Gerontology \& Geriatrics, 55, e48-e52.

https://doi.org/10.1016/j.archger.2012.05.002

[14] Iellamo, F., Volterrani, M., et al. (2010) Testosterone Therapy in Women with Chronic Heart Failure: A Pilot Double-Blind, Randomized, Placebo-Controlled Study. Journal of the American College of Cardiology, 56, 1310-1316.

https://doi.org/10.1016/j.jacc.2010.03.090

[15] Morley, J.E., Kaiser, F.E., et al. (1997) Longitudinal Changes in Testosterone, Luteinizing Hormone, and Follicle-Stimulating Hormone in Healthy Older Men. Metabolism Clinical \& Experimental, 46, 410-413. https://doi.org/10.1016/S0026-0495(97)90057-3

[16] Maggiolini, M. and Picard, D. (2010) The Unfolding Stories of GPR30, a New Membrane-Boundestrogen Receptor. Journal of Endocrinology, 204, 105-114. https://doi.org/10.1677/JOE-09-0242

[17] Taaffe, D.R. and Newman, A.B. (2005) Estrogen Replacement, Muscle Composition, and Physical Function: The Health ABC Study. Medicine \& Science in Sports \& EXercise, 37, 1741-1747. https://doi.org/10.1249/01.mss.0000181678.28092.31

[18] Skjöldebrand, S.L., Kollind, M., et al. (2002) Ovarian Ultrasound and Ovarian and Adrenal Hormones before and after Treatment for Hyperthyroidism. Gynecologic \& Obstetric Investigation, 54, 50-55. https://doi.org/10.1159/000065573

[19] Loric, S., Duron, F., et al. (1989) Testosterone and Its Binding in Hyperthyroid Women before and under Antithyroid Drug Therapy. Acta Endocrinologica, 121, 443-446. https://doi.org/10.1530/acta.0.1210443

[20] Gower, B.A. and Nyman, L. (2000) Associations among Oral Estrogen Use, Free Testosterone Concentration, and Lean Body Mass among Postmenopausal Women. The Journal of Clinical Endocrinology \& Metabolism, 85, 4476-4480. 
[21] Bian, A.L., Hu, H.Y., et al. (2017) A Study on Relationship between Elderly Sarcopenia and Inflammatory Factors Il-6 and TNF- $\alpha$. European Journal of Medical Research, 22, 25. https://doi.org/10.1186/s40001-017-0266-9

[22] Pereira, L.S., Narciso, F.M., et al. (2009) Correlation between Manual Muscle Strength and Interleukin-6 (IL-6) Plasma Levels in Elderly Community-Dwelling Women. Archives of Gerontology \& Geriatrics, 48, 313-316. https://doi.org/10.1016/j.archger.2008.02.012

[23] Goodman, M.J., Ghate, S.R., et al. (2013) Development of a Practical Screening Tool to Predict Low Muscle Mass Using NHANES 1999-2004. Journal of Cachexia, Sarcopenia and Muscle, 4, 187-197. https://doi.org/10.1007/s13539-013-0107-9 